\title{
Grazing management and supplementation effects on forage and dairy cow performance on cool-season pastures in the southeastern United States
}

\author{
B. Macoon, ${ }^{* 1}$ L. E. Sollenberger,† C. R. Staples, $\ddagger$ K. M. Portier,§ J. H. Fike,\# and J. E. Moorell \\ ${ }^{*}$ Central Mississippi Research and Extension Center, Mississippi State University, Raymond 39154 \\ †Department of Agronomy and \\ †Department of Animal Sciences, University of Florida, Gainesville 32611 \\ $\S D e p a r t m e n t$ of Statistics and Evaluation, American Cancer Society, Atlanta, GA 30329 \\ \#Department of Crop and Soil Environmental Sciences, Virginia Polytechnic Institute and State University, Blacksburg 24061 \\ IIProfessor Emeritus, Stillwater, OK 74074
}

\begin{abstract}
Cool-season annual forages provide high-quality herbage for up to 5 mo in the US Gulf Coast states, but their management in pasture-based dairy systems has received little attention. Objectives of this study were to evaluate pasture and animal responses when lactating Holstein cows $(\mathrm{n}=32$, mean DIM $=184 \pm 21)$ grazed either N-fertilized rye (Secale cereale L.)-annual ryegrass (Lolium multiflorum Lam.) mixed pastures or rye-annual ryegrass-crimson clover (Trifolium incarnatum L.)-red clover (Trifolium pratense L.) pastures at 2 stocking rates ( 5 vs. 2.5 cows/ha) and 2 rates of concentrate supplementation $[0.29$ or $0.40 \mathrm{~kg}$ of supplement (as is) $/ \mathrm{kg}$ of daily milk production]. Two cows paired by parity (one multiparous and one primiparous) were assigned randomly to each pasture. The $2 \times 2 \times 2$ factorial arrangement of treatments was replicated twice in a completely randomized design. Forage mixture and supplementation rate did not affect milk production during three 28 -d periods. Greater milk production occurred at the low $(19.7 \mathrm{~kg} / \mathrm{d})$ than the high $(14.7 \mathrm{~kg} / \mathrm{d})$ stocking rate during periods 2 and 3 , but production was similar during period 1. Despite lower production per cow, milk production per hectare was generally greater at the high stocking rate ( 81.6 vs. $49.5 \mathrm{~kg} / \mathrm{ha})$. Generally, greater pregraze herbage mass on pastures at the lower stocking rate (1,400 vs. $1,150 \mathrm{~kg} / \mathrm{ha})$ accounted for greater herbage allowance. Both forage (8.0 vs. 5.9 $\mathrm{kg} / \mathrm{d}$ ) and total (14.1 vs. 11.6) organic matter intake were greater at the low stocking rate. Cows fed less supplement had greater forage organic matter intake ( 8.0 vs. $6.1 \mathrm{~kg} / \mathrm{d}$ ). Greater herbage mass was associated with the greater intake and subsequent greater milk production. Differences in forage nutritive value, blood metabolites and milk composition, although showing
\end{abstract}

Received October 19, 2010.

Accepted March 25, 2011.

${ }^{1}$ Corresponding author: bmacoon@ra.msstate.edu some response to treatments, may not be of sufficient magnitude to affect choice of pasture species or other management practices. Animal performance was not improved by adding clovers to mixed cool-season grass pastures like those in this study. Stocking rate had a major effect on pasture and animal performance. During the cool season, supplementation with concentrates should be planned based on estimated energy intake from forages to achieve optimum milk production and ensure maintenance of body condition.

Key words: dairy cow, grazing, pasture

\section{INTRODUCTION}

Florida's dairy industry is an integral part of the state's agriculture with revenues from milk sales approaching $\$ 400$ million annually (NASS, 2009). Most Florida dairies have large herds, use stored forage, and feed TMR to animals in freestall housing. Pastures are not considered to be a source of nutrition for dairy cows and are often used as exercise lots for dry cows and heifers. A segment of the dairy industry in the Lower South uses grazed pasture to supply the forage component of the diet. Insufficient information is available on species selection, grazing management, and supplementation practices for dairy cows grazing cool-season pastures.

Grazing management decisions for Florida's winter pastures should be based on data that link animal responses to pasture production and explain the interactions among these components. It is well established that animal performance is largely determined by nutrient consumption (Mertens, 1994), which, for grazing animals, is influenced by pasture characteristics, environmental conditions, and management factors. Herbage mass (HM) or allowance (Dougherty et al., 1992; Holmes et al., 1992) and pasture quality (Hoogendoorn et al., 1992) are major determinants of intake and, hence, animal performance on pasture-based systems. Fontaneli et al. (2001) reported that rye (Secale cereale L.), annual ryegrass (Lolium multiflorum Lam.), and 
clovers (Trifolium sp.) are valuable forages for winter pasture programs in northern Florida. The use of clovers in mixed swards with cool-season annual grasses may decrease expenditures for $\mathrm{N}$ fertilizer and increase forage quality (Baltensperger et al., 1986; Moss and Lowe, 1993).

Stocking rate (SR) is a key management variable influencing productivity and profitability of grazing systems (Fales et al., 1995) because it determines herbage allowance (HA) and affects HM and nutritive value (Burns and Sollenberger, 2002; Sollenberger et al., 2005; Sollenberger and Vanzant, 2011). Although high nutrient intake from pasture may be possible, the high nutrient requirements of lactating dairy cows necessitate concentrate supplementation so that near potential milk production may be achieved (Kolver and Muller, 1998). To decrease production costs, concentrate supplementation studies on pasture-based systems need to focus on feeding rates that ensure maximum nutrient intake from pasture while decreasing substitution of forage for concentrate.

This research addressed species selection and grazing management of cool-season forages during winter months in Florida. The objective was to quantify pasture and animal responses when lactating dairy cows grazed 2 different cool-season forage mixtures [N-fertilized rye and annual ryegrass vs. rye-annual ryegrass-crimson clover (Trifolium pratense L.)-red clover (Trifolium incarnatum L.)] at 2 SR (5 vs. 2.5 cows/ha) and were supplemented at 2 rates $[0.29$ or $0.40 \mathrm{~kg}$ of supplement (as is) $/ \mathrm{kg}$ of daily milk production].

\section{MATERIALS AND METHODS}

The study was conducted during the 1996-1997 winter at the University of Florida Dairy Unit at Hague $\left(29^{\circ} 46^{\prime} \mathrm{N} ; 82^{\circ} 24^{\prime} \mathrm{W}\right), 18 \mathrm{~km}$ north of Gainesville. The approximately 10-ha experimental area was mapped as a heterogeneous mixture of Chipley fine sand (thermic, coated, Aquic Quartzipsamments) with less than 5\% slope, Sparr fine sand (loamy, siliceous, hyperthermic, Grossarenic Paleudults), and Tavares fine sand (hyperthermic, uncoated, Typic Quartzipsamments), both with 0 to $5 \%$ gradient. These soils are somewhat poorly to moderately well drained. Prior to initiation of grazing at the site, the mean soil $\mathrm{pH}\left(1: 2\right.$ soil:deionized $\mathrm{H}_{2} \mathrm{O}$ ratio) was 5.9, and Mehlich-I (0.05 $M$ HCL + $0.0125 M$ $\mathrm{H}_{2} \mathrm{SO}_{4}$ ) extractable $\mathrm{P}, \mathrm{K}, \mathrm{Mg}$, and $\mathrm{Ca}$ in the $\mathrm{A} 1$ horizon (0- to $15-\mathrm{cm}$ depth) were $99,26,50$, and $598 \mathrm{mg} / \mathrm{kg}$, respectively.

Treatments were the factorial combinations of (1) forage mixtures $(\mathbf{F M})$ : N-fertilized rye-annual ryegrass (N-fertilized grass) vs. rye-annual ryegrass-crimson clover-red clover (grass-clover), (2) SR: 2.5 (low) vs. 5 cows/ha (high), and (3) concentrate supplementation rates (CS): 0.29 (low) vs. 0.40 (high) kg of supplement (as is) per kilogram of daily milk production. The SR were selected based upon previous research with coolseason forages (Baltensperger et al., 1986). The $2 \times 2$ $\times 2$ factorial arrangement of treatments was replicated twice in a completely randomized design, resulting in a total of 16 pastures (experimental units). The pasture area was 0.8 ha for the low-SR treatment and 0.4 ha for the high-SR treatment.

Pastures were sod seeded in mid-October 1996. Forage cultivars used were Grazemaster rye (a blend of several maturity types), Surrey annual ryegrass, Cherokee red clover, and Dixie crimson clover. For the ryeannual ryegrass mixture, seeding rates were $90 \mathrm{~kg} / \mathrm{ha}$ for rye and $17 \mathrm{~kg} /$ ha for ryegrass. For the grass-clover mixture, seeding rates were $67 \mathrm{~kg} / \mathrm{ha}$ for rye, $11 \mathrm{~kg} /$ ha for annual ryegrass, $10 \mathrm{~kg} / \mathrm{ha}$ for crimson clover, and $6 \mathrm{~kg} / \mathrm{ha}$ for red clover. All pastures received an initial application of $40 \mathrm{~kg}$ of $\mathrm{N} / \mathrm{ha}$ as $\mathrm{NH}_{4} \mathrm{NO}_{3}$ and 40 $\mathrm{kg}$ of $\mathrm{K}_{2} \mathrm{O}$ /ha during establishment. An additional 40 $\mathrm{kg}$ of $\mathrm{N} / \mathrm{ha}$ was applied to all pastures when the trial began. Subsequently, $40 \mathrm{~kg}$ of $\mathrm{N} / \mathrm{ha}$ were applied to $\mathrm{N}$-fertilized grass pastures during the fifth and ninth week of the 12 -wk study. The experimental protocol did not include any additional fertilizer application to grass-clover pastures, but because of poor grass growth, $40 \mathrm{~kg}$ of N/ha was applied during the sixth week. Thus, the $\mathrm{N}$-fertilized grass system received a total of $160 \mathrm{~kg}$ of $\mathrm{N} / \mathrm{ha}$, whereas grass-clover mixtures received $120 \mathrm{~kg}$ $\mathrm{N} /$ ha.

Compared with the 70-yr average of monthly rainfall for Gainesville (72, 94, 108, and $77 \mathrm{~mm}$, respectively), rainfall in January $(72 \mathrm{~mm}$ ) was the same, February (36 $\mathrm{mm})$ and March $(87 \mathrm{~mm})$ rainfall were lower, and April rainfall $(182 \mathrm{~mm})$ was greater during the experiment. The rainfall total for the November through January period before initiation of grazing (coinciding with establishment phase of pastures) was $239 \mathrm{~mm}$ compared with the 70-yr average of $195 \mathrm{~mm}$. Temperatures during the study were generally greater than average temperatures for the area. The average temperature in January was $13.8^{\circ} \mathrm{C}$, close to the 70 -yr normal of $13.4^{\circ} \mathrm{C}$, but February $\left(16.4^{\circ} \mathrm{C}\right)$ and March $\left(20.8^{\circ} \mathrm{C}\right)$ were warmer than the normal of 14.3 and $17.7^{\circ} \mathrm{C}$, respectively. The April temperature $\left(18.9^{\circ} \mathrm{C}\right)$ was somewhat cooler than the 70 -yr average $\left(20.6^{\circ} \mathrm{C}\right)$.

Experimental animals were assigned to treatments on January 13 and pasture and animal responses were measured during 3 continuous 28 -d periods, ending April 7. At the beginning of the trial, 2 lactating Holstein cows paired by parity (one primiparous and one multiparous) were assigned randomly to each pasture. A given pasture received the same management treat- 
ment in each period, but cows $(\mathrm{n}=32$, mean DIM $=$ $184 \pm 21$ ) were reassigned randomly to a new treatment each successive period with the restriction that no cow received the same treatment more than once during the experiment. Also, no 2 cows were together more than once but parity pairing was maintained. Pastures were subdivided using polywire fencing for rotational stocking so that cows were offered a fresh paddock every morning. Nitrogen-fertilized grass pastures were subdivided into 22 paddocks and grass-clover pastures into 29 paddocks to allow for 21- and 28-d rest periods, respectively, between grazing. A longer regrowth interval was provided for the grass-clover mixture because growth rate of clover is generally lower than that of well-fertilized ryegrass (Chapman et al., 2007). Cows were allowed 2 paddocks at a time to give them additional room for movement, so during every 24-h period they were on the paddock that was grazed the previous day and a fresh paddock. Animals walked approximately $2.4 \mathrm{~km}$ per round trip to the parlor to be milked twice daily at 0500 and $1700 \mathrm{~h}$.

Concentrate supplement (Table 1) was group fed to each experimental unit after each milking in troughs located in each pasture. The supplement was formulated to balance for $\mathrm{CP}$ and energy requirements of lactating dairy cows (NRC, 2001) based on what would be missing if fed a forage alone diet. The amount of supplement fed per experimental group was recalculated twice weekly based on average milk production during the preceding 3- to 4 -d period. A minimum of $4.5 \mathrm{~kg}$ of supplement (as is)/cow was fed each day. All pastures had water tubs fitted with float-control devices to ensure continuous availability of drinking water. Feed troughs and water tubs were moved daily to the new paddocks.

Pasture and animal responses to the treatments were measured during each period. The first $14 \mathrm{~d}$ of each period were considered an adaptation phase, and animal response data were recorded during the latter 14 $\mathrm{d}$ of the period. At the end of the first week of period 2 , animals were taken off the high-SR treatments on grass-clover pastures because of low HM. These animals were kept in the barn and fed TMR until returned to experimental pastures at the beginning of period 3 . Animal responses from these treatments during period 2 were considered missing data.

\section{Pasture Variables}

Estimation of pre- and postgraze HM was done weekly in each period using a double sampling technique (Burns et al., 1989). Pregraze measures were taken in paddocks to be grazed the following day and postgraze measures were taken the day after cattle vacated a paddock. Indirect estimates of HM were taken using a $0.25-\mathrm{m}^{2}$ disk meter at 20 randomly selected sites per paddock. The disk meter was calibrated at the first and third weekly sampling during each period. Three sites were selected in each paddock to represent low, intermediate, and high HM. Herbage in circular quadrats of the same area as the disk meter $\left(0.25 \mathrm{~m}^{2}\right)$ was harvested to a 3 -cm stubble height using battery-powered hand clippers. Harvested samples were dried at $60^{\circ} \mathrm{C}$ in a forcedair oven until constant weight was achieved. Linear regression was used to develop equations relating direct (harvested sample) and indirect (disk meter height) measures of HM on pastures. Equations developed for a particular double sampling date were used to estimate HM for that date and for the indirect measures taken the following week. Herbage removed from pasture during grazing (herbage disappearance) was the difference between pregraze and postgraze HM.

Samples to estimate nutritive value of grazed herbage were taken 4 times (once weekly) during each of the 3 periods. Hand-plucked samples were taken and composited from 15 to 20 random sites in the paddock that was to be grazed the following day. Sample selec-

Table 1. Ingredient and chemical composition of supplement fed to lactating Holstein cows on winter pastures

\begin{tabular}{|c|c|}
\hline Item & Amount \\
\hline \multicolumn{2}{|l|}{ Ingredient, $\%$ of DM } \\
\hline Hominy & 29.5 \\
\hline Soybean hulls & 22.5 \\
\hline Whole cottonseed & 19.2 \\
\hline Citrus pulp & 15.0 \\
\hline Dried distillers grains with solubles & 6.0 \\
\hline Fish meal & 2.5 \\
\hline Mineral $\operatorname{mix}^{1}$ & 3.2 \\
\hline Trace mineralized salt ${ }^{2}$ & 0.25 \\
\hline Sodium bicarbonate & 1.6 \\
\hline Magnesium oxide & 0.25 \\
\hline $\mathrm{DM}, \%$ & 89.5 \\
\hline $\mathrm{NE}_{\mathrm{L}},{ }^{3} \mathrm{Mcal} / \mathrm{kg}$ of $\mathrm{DM}$ & 1.87 \\
\hline \multicolumn{2}{|l|}{ Chemical composition } \\
\hline NDF, \% of DM & 36.3 \\
\hline $\mathrm{ADF}, \%$ of $\mathrm{DM}$ & 23.8 \\
\hline $\mathrm{CP}, \%$ of DM & 16.2 \\
\hline $\mathrm{Ca}, \%$ of $\mathrm{DM}$ & 0.90 \\
\hline $\mathrm{P}, \%$ of $\mathrm{DM}$ & 0.47 \\
\hline $\mathrm{Mg}, \%$ of $\mathrm{DM}$ & 0.45 \\
\hline $\mathrm{K}, \%$ of $\mathrm{DM}$ & 1.16 \\
\hline $\mathrm{Na}, \%$ of $\mathrm{DM}$ & 0.87 \\
\hline S, \% of DM & 0.18 \\
\hline $\mathrm{Cl}, \%$ of $\mathrm{DM}$ & 0.40 \\
\hline $\mathrm{Fe}, \mathrm{mg} / \mathrm{kg}$ of $\mathrm{DM}$ & 298 \\
\hline $\mathrm{Zn}, \mathrm{mg} / \mathrm{kg}$ of $\mathrm{DM}$ & 89 \\
\hline $\mathrm{Cu}, \mathrm{mg} / \mathrm{kg}$ of $\mathrm{DM}$ & 20 \\
\hline $\mathrm{Mn}, \mathrm{mg} / \mathrm{kg}$ of $\mathrm{DM}$ & 71 \\
\hline
\end{tabular}

${ }^{1}$ Composition: $3.8 \% \mathrm{~N}, 10.5 \% \mathrm{Ca}, 3 \% \mathrm{P}, 4.5 \% \mathrm{~K}, 2 \% \mathrm{Mg}, 7.4 \% \mathrm{Na}$, $1.1 \% \mathrm{~S}, 5.4 \% \mathrm{Cl}, 1,525 \mathrm{mg}$ of $\mathrm{Mn} / \mathrm{kg}, 1,750 \mathrm{mg}$ of $\mathrm{Fe} / \mathrm{kg}, 425 \mathrm{mg}$ of $\mathrm{Cu} / \mathrm{kg}, 1,500 \mathrm{mg}$ of $\mathrm{Zn} / \mathrm{kg}, 12.8 \mathrm{mg}$ of $\mathrm{I} / \mathrm{kg}, 49 \mathrm{mg}$ of $\mathrm{Co} / \mathrm{kg}, 24.2 \mathrm{IU}$ of vitamin A/g, 35.2 IU of vitamin D/g, and $0.88 \mathrm{IU}$ of vitamin $\mathrm{E} / \mathrm{g}$. ${ }^{2}$ Composition (g/100 g): $\mathrm{NaCl}, 92 ; \mathrm{Mn}, 0.25 ; \mathrm{Fe}, 0.2 ; \mathrm{Cu}, 0.033 ; \mathrm{I}$, 0.007; Zn, 0.005; and CO, 0.0025 .

${ }^{3}$ Calculated using 1989 NRC values for whole cottonseed. 
tion was based on observation of the adjacent grazed paddock to represent the herbage consumed by grazing animals. These samples were dried approximately $72 \mathrm{~h}$ at $60^{\circ} \mathrm{C}$ in a forced-air oven and ground in a Thomas Wiley laboratory mill (Thomas Scientific, Swedesboro, NJ) to pass a 1-mm stainless steel screen. Samples for N analysis were digested using a modified aluminum block digestion procedure (Gallaher et al., 1975). Ammonia in the digestate was determined using semi-automated colorimetry (Hambleton, 1977) and CP (DM basis) was calculated $(\mathrm{N}$ concentration $\times 6.25)$. Herbage in vitro OM digestibility (IVOMD) was determined using a modification of the 2-stage procedure (Moore and Mott, 1974). Herbage NDF concentration was determined using techniques outlined by Golding et al. (1985).

\section{Plant-Animal Interface Variables}

Herbage allowance is kilograms of HM per kilogram of animal BW during the grazing period (Sollenberger et al., 2005). Average HM was calculated as $0.5 \times$ (pregraze $\mathrm{HM}+$ postgraze $\mathrm{HM}, \mathrm{kg} / \mathrm{ha}$ ) and average animal $\mathrm{BW}$ as $0.5 \times(\mathrm{BW}$ at beginning of period $+\mathrm{BW}$ at end of period, $\mathrm{kg} /$ cow $\times$ cow $/$ ha $)$.

Estimates of OM intake (OMI) were done by back calculating energy requirements based on animal performance (NRC, 2001) and using estimates of energy concentration of the feeds offered to the animals. Macoon et al. (2003) described in detail the procedures used for estimation of energy requirements for the animals in this study. Analysis of supplement feed was done at the DHIA Forage Testing Laboratory (Ithaca, NY).

\section{Animal Response Variables}

Milk yield was recorded at each milking but only data during the latter $14 \mathrm{~d}$ of each period were used to assess responses. Milk samples were taken at 6 consecutive milkings during each of the last $2 \mathrm{wk}$ of each period and sent to a commercial laboratory (Southeast Dairy Laboratory Inc., McDonough, GA) for analysis of milk fat, milk protein, and MUN concentrations, and SCC using a Bentley 2000 NIR analyzer (Bentley Instruments, Chaska, MN).

All animals were weighed for 3 consecutive days at the beginning of the trial and at the end of each period. Weighing was done after the morning milking and before feeding of supplements. Average BW was the mean weight of the $3 \mathrm{~d}$.

\section{Statistical Analysis}

All responses were analyzed by fitting mixed effects models (Littell et al., 1996) using the PROC MIXED procedure of SAS (SAS Institute, 1991). The model used was

$$
\begin{gathered}
\mathrm{Y}_{i j k l}=\mu+\mathrm{P}_{i}+\mathrm{F}_{j}+(\mathrm{PF})_{i j}+\mathrm{S}_{k}+(\mathrm{PS})_{i k}+(\mathrm{FS})_{j k} \\
+(\mathrm{PFS})_{i j k}+\mathrm{C}_{l}+(\mathrm{PC})_{i l}+(\mathrm{FC})_{j l}+(\mathrm{SC})_{k l}+(\mathrm{PFC})_{i j l} \\
+(\mathrm{PSC})_{i k l}+(\mathrm{PFSC})_{i j k l}+\mathrm{e}_{i j k l},
\end{gathered}
$$

where $\mathrm{Y}_{i j k l}$ is the dependent variable, $\mu$ is the overall mean, $\mathrm{P}_{i}$ is the period effect, $\mathrm{F}_{j}$ is the FM effect, $(\mathrm{PF})_{i j}$ is the period $\times \mathrm{FM}$ interaction, $\mathrm{S}_{k}$ is the $\mathrm{SR}$ effect, $(\mathrm{PS})_{i k}$ is the period $\times \mathrm{SR}$ interaction, $(\mathrm{FS})_{j k}$ is the $\mathrm{FM} \times \mathrm{SR}$ interaction, $(\mathrm{PFS})_{i j k}$ is the period $\times \mathrm{FM} \times$ SR interaction, $\mathrm{C}_{l}$ is the CS effect, $(\mathrm{PC})_{i l}$ is the period $\times \mathrm{CS}$ interaction, $(\mathrm{FC})_{j l}$ is the $\mathrm{FM} \times \mathrm{CS}$ interaction, $(\mathrm{SC})_{k l}$ is the $\mathrm{SR} \times \mathrm{CS}$ interaction, $(\mathrm{PFC})_{i j l}$ is the period $\times \mathrm{FM} \times \mathrm{CS}$ interaction, $(\mathrm{PSC})_{i k l}$ is the period $\times \mathrm{SR} \times$ $\mathrm{CS}$ interaction, $(\mathrm{PFSC})_{i j k l}$ is the period $\times \mathrm{FM} \times \mathrm{SR} \times$ CS interaction, and $\mathrm{e}_{i j k l}$ is the residual error.

All effects were considered fixed except for the error term, which was considered random. Period in the model was considered to be a repeated measure in time because it did not have a chance to be assigned randomly (Littell et al., 1996). Subject (pasture or animal pair) was the experimental unit, that is, each replication $\times \mathrm{FM} \times \mathrm{SR} \times \mathrm{CS}$ combination. Mean separations using probability of difference tests (PDIFF in SAS; SAS Institute, 1991) were conducted only for effects that were statistically significant $(P<0.05)$ or where a trend $(P>0.05$ but $<0.10)$ existed. Means reported are least squares means and were considered different at $P<0.05$, unless otherwise stated. Regression and correlation techniques (PROC REG and PROC CORR procedures in SAS; SAS Institute, 1991) were used to explore relationships between variables.

\section{RESULTS AND DISCUSSION}

\section{Herbage Mass}

Pregraze HM was affected by a period $\times \mathrm{FM} \times \mathrm{SR}$ interaction $(P=0.01)$. During period 1 , the mean pregraze $\mathrm{HM}$ was $1,700 \mathrm{~kg}$ of $\mathrm{DM} / \mathrm{ha}$ and was unaffected by treatment (Table 2). The lack of differences during period 1 was because paddocks either had not been grazed or had been subjected to treatments for only a short time before measurements being taken. During period 2, low-SR pastures had greater pregraze HM than did high-SR pastures, regardless of FM $(1,170$ vs. $690 \mathrm{~kg}$ of DM/ha, respectively). In a New Zealand study using perennial ryegrass (Lolium perenne L.)white clover (Trifolium repens L.) pastures, L'Huillier (1987) reported no differences in pregraze HM when 
the grazing season started, but greater pregraze HM was associated with lower SR as the season progressed. Many other grazing studies have demonstrated greater HM at lenient SR (Moss and Lowe, 1993; Fales et al., 1995). Also in period 2, N-fertilized grass pastures had greater pregraze HM than grass-clover pastures, regardless of SR (1,170 vs. $690 \mathrm{~kg}$ of DM/ha, respectively; Table 2). Legume herbage accumulation is minimal during winter (Fontaneli et al., 2001), so N fertilization has a greater relative effect on accumulation during that season. In period 3, increased SR on the N-fertilized pastures decreased pregraze HM (750, high SR, vs. $1,420 \mathrm{~kg}$ of $\mathrm{DM} / \mathrm{ha}$, low SR) but HM was unaffected by SR in grass-clover pastures $(1,360$, high SR, vs. $1,350 \mathrm{~kg}$ of $\mathrm{DM} /$ ha, low SR). Absence of SR effect on grass-clover pasture HM in period 3 occurred because cows had been removed from the greater SR treatment during period 2 because of low HM.

Pregraze HM increased from 1,350 to $1,690 \mathrm{~kg}$ of $\mathrm{DM} /$ ha with increasing rate of CS when cows grazed the $\mathrm{N}$-fertilized grass pastures at the low SR. For the other $3 \mathrm{FM}$ and SR treatment combinations, pregraze $\mathrm{HM}$ decreased as the rate of $\mathrm{CS}$ increased $(\mathrm{FM} \times \mathrm{SR}$ $\times$ CS interaction, $P=0.04$; Table 2). With HM not as limiting for cows grazing $\mathrm{N}$-fertilized pastures at low SR, additional supplement likely decreased grazing time and the DMI.

\section{Herbage Allowance}

Regardless of FM or CS rate, low-SR pastures had greater HA than did high-SR pastures (Table 2). An $\mathrm{FM} \times \mathrm{SR} \times \mathrm{CS}$ interaction was observed $(P<0.01)$. It occurred primarily because HA was greater for low-SR, $\mathrm{N}$-fertilized grass system pastures when CS was high than when it was low, whereas no differences existed due to $\mathrm{CS}$ for other FM $\times \mathrm{SR}$ combinations. This was the same treatment that had greatest pregraze HM (Table 2).

The $\mathrm{N}$-fertilized grass pastures $(0.87 \mathrm{~kg}$ of $\mathrm{DM} / \mathrm{kg}$ of BW) had greater HA than did grass-clover pastures $(0.64 \mathrm{~kg}$ of $\mathrm{DM} / \mathrm{kg}$ of $\mathrm{BW})$ during period 1 but $\mathrm{FM}$ did not differ in periods $2(0.55$ vs. $0.59 \mathrm{~kg}$ of $\mathrm{DM} / \mathrm{kg}$ of BW) or 3 (0.50 vs. $0.51 \mathrm{~kg}$ of DM/ $\mathrm{kg}$ of BW, FM $\times$ period interaction, $P<0.01)$. These data must be interpreted with caution because high-SR pastures in the grass-clover system were not grazed during the latter 3 wk of period 2. The extended regrowth interval allowed grass-clover pastures to have similar HA to N-fertilized grass pastures during period 3 .

\section{Forage Nutritive Value}

In Vitro OM Digestibility. Herbage IVOMD was not affected by FM at high SR (694 vs. $689 \mathrm{~g} / \mathrm{kg}$ for grass-clover and $\mathrm{N}$-fertilized grass, respectively), but at low SR, IVOMD was greater for N-fertilized grass $(690 \mathrm{~g} / \mathrm{kg})$ than for grass-clover pastures $(666 \mathrm{~g} / \mathrm{kg}$, FM $\times$ SR interaction, $P=0.02$; Table 3$)$. The latter response possibly reflects the longer regrowth interval for grass-clover ( $28 \mathrm{~d}$ ) than N-fertilized grass systems (21 d), a maturity effect that was significant only when postgraze HM was greater on low-SR pastures.

No difference was observed in IVOMD between FM during period 1 but IVOMD was greater for the $\mathrm{N}$ fertilized grass mixture than for the grass-clover mixture during period $2(708$ vs. $672 \mathrm{~g} / \mathrm{kg}$ ) and period 3 (691 vs. $663 \mathrm{~g} / \mathrm{kg}, \mathrm{FM} \times$ period interaction, $P=0.03$; Table 3 ). The difference in period 3 was likely because of, in part, the high-SR grass-clover pastures not being

Table 2. Forage mixture (FM; N-fertilized grasses or grass-clover mixture), stocking rate (SR; high $=5$ cows/ha, low $=2.5$ cows $/$ ha), and concentrate supplement rate $[\mathrm{CS}$; high $=0.40$ and low $=0.29 \mathrm{~kg}$ of supplement (as fed) $/ \mathrm{kg}$ of milk per day] effect on pregraze herbage mass (HM) and herbage allowance (HA) during 3 consecutive 28-d periods

\begin{tabular}{|c|c|c|c|c|c|c|c|c|c|c|}
\hline Item & Period & \multicolumn{4}{|c|}{ N-fertilized grass mixture } & \multicolumn{4}{|c|}{ Grass-clover mixture } & $\mathrm{SEM}^{1}$ \\
\hline \multirow[t]{2}{*}{$\mathrm{HM}, \mathrm{kg}$ of $\mathrm{DM} / \mathrm{ha}$} & 1 & 1,750 & 1,840 & 1,960 & 1,610 & 1,650 & 1,630 & 1,440 & 1,750 & \multirow[b]{2}{*}{125} \\
\hline & 2 & 940 & 1,000 & 1,560 & 1,180 & 420 & 390 & 910 & 1,030 & \\
\hline (l) & 2 & 0.28 & 0.27 & 0.95 & 0.69 & $\mathrm{ND}^{2}$ & ND & 0.53 & 0.63 & \multirow[t]{2}{*}{0.06} \\
\hline & 3 & 0.17 & 0.18 & 0.92 & 0.72 & 0.27 & 0.35 & 0.58 & 0.84 & \\
\hline
\end{tabular}

${ }^{1} \mathrm{SEM}$ of 4-way interaction means (NS, $P>0.10$ ). Within responses, the significant effects are (a) pregraze HM, period $\times$ FM $\times$ SR interaction $(P=0.013, \mathrm{SEM}=88.4)$ and $\mathrm{FM} \times \mathrm{SR} \times \mathrm{CS}$ interaction $(P=0.037, \mathrm{SEM}=80.9) ;(\mathrm{b}) \mathrm{HA}, \mathrm{FM} \times \mathrm{SR} \times \mathrm{CS}$ interaction $(P=0.008, \mathrm{SEM}=$ $0.040)$ and period $\times$ FM interaction $(P=0.003, \mathrm{SEM}=0.033)$.

${ }^{2}$ No data because cows were removed from these treatments for $3 \mathrm{wk}$ because of low HM. 
Table 3. Forage mixture (FM; N-fertilized grasses or grass-clover mixture), stocking rate (SR; high $=5$ cows $/$ ha, low $=2.5$ cows $/$ ha), and concentrate supplement rate $[\mathrm{CS}$; high $=0.40$ and low $=0.29 \mathrm{~kg}$ of supplement (as fed) $/ \mathrm{kg}$ of milk per day] effect on forage in vitro OM digestibility (IVOMD), CP, and NDF during 3 consecutive 28-d periods

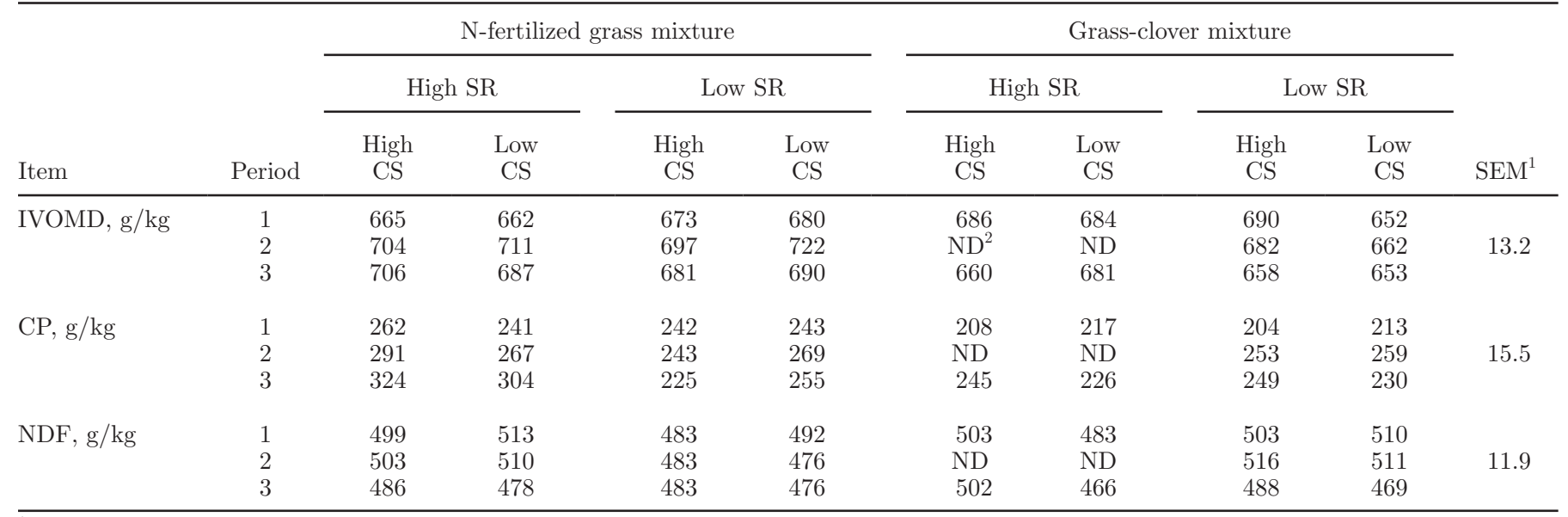

${ }^{1}$ SEM of 4-way interaction means (NS, $\left.P>0.10\right)$. Within responses, the significant effects are (a) IVOMD, FM $\times$ SR interaction $(P=0.02$, $\mathrm{SEM}=5.2)$ and period $\times \mathrm{FM}$ interaction $(P=0.03, \mathrm{SEM}=6.6) ;(\mathrm{b}) \mathrm{CP}$, period $\times \mathrm{FM} \times \mathrm{SR}$ interaction $(P=0.02, \mathrm{SEM}=10.6) ;$ and $(\mathrm{c})$ $\mathrm{NDF}$, period $\times \mathrm{FM} \times \mathrm{SR}$ interaction $(P=0.04, \mathrm{SEM}=10.2)$.

${ }^{2}$ No data because cows were removed from these treatments for 3 wk because of low herbage mass.

grazed for the latter 3 wk of period 2 , thus leading to increased maturity of the forage during period 3. In general, although treatment effects on IVDOM were detected, they may have been too small to affect animal performance.

CP Concentration. During period 1, herbage $\mathrm{CP}$ content was greater for $\mathrm{N}$-fertilized grass [251 g/ $\mathrm{kg}$ (high SR) and $242 \mathrm{~g} / \mathrm{kg}$ (low SR)] compared with grass-clover $[213 \mathrm{~g} / \mathrm{kg}$ (high SR) and $209 \mathrm{~g} / \mathrm{kg}$ (low SR)] pastures, regardless of SR. No CP differences due to FM or SR were detected during period 2 (range of 256 to $281 \mathrm{~g} / \mathrm{kg}$ ). During period 3, CP was greatest for the $\mathrm{N}$-fertilized grass system managed with higher SR $(313 \mathrm{~g} / \mathrm{kg}$ ) compared with all other treatments (range of 235 to $240 \mathrm{~g} / \mathrm{kg}, \mathrm{FM} \times \mathrm{SR} \times$ period interaction, $P$ $=0.02$ ). Less forage maturity resulting from the shorter regrowth interval (21 vs. 28 d) may partly explain the greater $\mathrm{CP}$ of the $\mathrm{N}$-fertilized system. Further, in period 3 , the greater $\mathrm{CP}$ of forage sampled from the high-SR $\mathrm{N}$-fertilized grass treatment likely was because of the presence of younger regrowth because of more intensive grazing. Fales et al. (1995) reported CP ranging from $236 \mathrm{~g} / \mathrm{kg}$ for a low SR (1 cow/ha) to $273 \mathrm{~g} / \mathrm{kg}$ at high SR (1.6 cow/ha) in their study on temperate pastures.

NDF. Forage NDF concentrations were not affected by FM or SR during periods 1 (mean of $498 \mathrm{~g} / \mathrm{kg}$ ) and 3 (481 g/kg). For the grass-clover mixture, however, $\mathrm{NDF}$ was greater than that of the $\mathrm{N}$-fertilized grass mixture managed at the low SR during period 2 (513 vs. $480 \mathrm{~g} / \mathrm{kg}, \mathrm{FM} \times \mathrm{SR} \times$ period interaction, $P=0.04$; Table 3). As with IVOMD, NDF data showed treat- ment effects but the magnitude of differences may not be large enough to affect animal performance.

\section{OM Intake}

Forage OMI was greater $(P<0.001)$ for cows grazing low-SR treatments $(8.00 \mathrm{~kg} / \mathrm{d})$ vs. high-SR $(5.92 \mathrm{~kg} / \mathrm{d})$ treatments and also was greater $(P=0.001)$ for cows on low CS $(7.99 \mathrm{~kg} / \mathrm{d})$ vs. high CS $(6.11 \mathrm{~kg} / \mathrm{d}$; Table 4). Cows grazing during period 3 had greater forage OMI than during period 1 (9.72 vs. $6.05 \mathrm{~kg} / \mathrm{d}, P<$ $0.001)$. The total OMI was affected by a period $\times \mathrm{SR}$ interaction $(P<0.05)$. In both periods 1 and 3 , the total OMI of cows was greater on the low- vs. high-SR treatments (13.14 vs. $11.21 \mathrm{~kg} / \mathrm{d}$ in period 1 and 16.09 vs. $11.95 \mathrm{~kg} / \mathrm{d}$ in period 3; Table 4). The interaction was partially because of differences in responses at different SR. At high SR, the total OMI of cows was not different between periods 1 and 3 but at low SR, the total OMI was greater during period $3(16.08 \mathrm{~kg} / \mathrm{d})$ compared with periods $1(13.14 \mathrm{~kg} / \mathrm{d})$ and $2(12.96$ $\mathrm{kg} / \mathrm{d}$; Table 4).

The pattern of forage intake response is related to pregraze HM. Generally, treatments where cows had greater forage OMI were those with greater pregraze HM and greater HA. In a UK study, dairy cows grazing swards with greater pregraze HM had $2.9 \mathrm{~kg}$ of DM more daily herbage intake than those grazing low-density swards with lower pregraze HM (Fisher et al., 1996). The CS effects on forage OMI suggest that animals tended to consume less forage when fed at the 
Table 4. Forage mixture (FM; N-fertilized grasses or grass-clover mixture), stocking rate (SR; high $=5$ cows $/$ ha, low $=2.5$ cows $/$ ha), and concentrate supplement rate $[\mathrm{CS}$; high $=0.40$ and low $=0.29 \mathrm{~kg}$ of supplement (as fed) $/ \mathrm{kg}$ of milk per day] effect on daily milk, FCM production per cow and per land area, and forage and total OM intake (OMI) during 3 consecutive 28-d periods

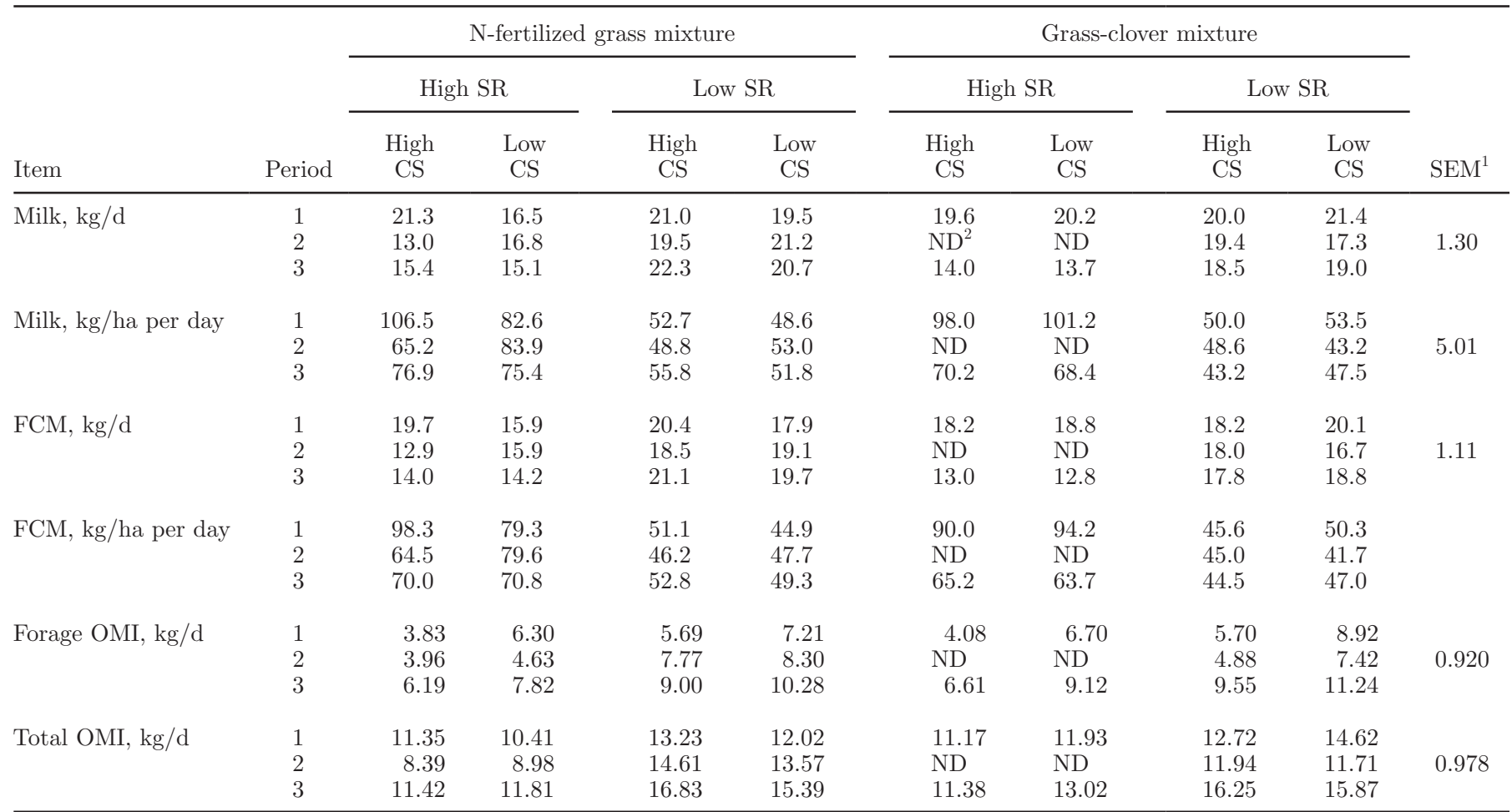

${ }^{1}$ SEM of 4-way interaction means (NS, $\left.P>0.10\right)$. Within responses, the significant effects are (a) milk per cow, period $\times$ SR interaction $(P<$ $0.01, \mathrm{SEM}=0.65)$; (b) milk per ha, period $\times$ SR interaction $(P<0.001$, SEM $=2.50)$; (c) FCM per cow, period $\times$ SR interaction $(P<0.01$, $\mathrm{SEM}=0.55)$; (d) FCM per ha, period $\times \mathrm{SR}$ interaction $(P<0.001, \mathrm{SEM}=2.13)$; (e) forage OMI, period $(P<0.001, \mathrm{SEM}=0.364), \mathrm{SR}(P<$ $0.001)$, and CS $(P=0.002)$ main effects, and $(\mathrm{f})$ total OMI, period $\times$ SR interaction $(P<0.05, \mathrm{SEM}=0.564)$.

${ }^{2}$ No data because cows were removed from these treatments for $3 \mathrm{wk}$ because of low herbage mass.

higher supplement level, and as a result, no statistical differences due to the rate of CS could be detected for total OMI. Additionally, its effects on pregraze HM suggest that a greater rate of CS played a role in pasture production, allowing accumulation of HM, likely because of more lenient grazing. The combined effects of HA and forage digestibility may have led to the observed forage and total OMI responses. Hoogendoorn et al. (1992) found that daily DMI increased when HA was increased, more so when herbage digestibility was greater. Estimates of intake in the present study fall within the range of intakes reported in the literature for lactating Holstein cows on pasture (Muller et al., 1995).

\section{Milk Production per Cow}

Milk production was not affected by FM or CS ( $P$ $>0.10$ ), or any interactions involving these treatments $(P>0.05)$. The mean daily milk production was not affected by SR during period 1 but was greater for cows kept at the low vs. high SR in periods 2 (19.3 vs. $14.9 \mathrm{~kg} / \mathrm{d})$ and $3(20.1$ vs. $14.5 \mathrm{~kg} / \mathrm{d}, \mathrm{SR} \times$ period interaction, $P<0.01$; Table 4). Within the high-SR treatments, milk production per cow was greater during period $1(19.4 \mathrm{~kg} / \mathrm{d})$ than periods $2(14.9 \mathrm{~kg} / \mathrm{d})$ and $3(14.5 \mathrm{~kg} / \mathrm{d})$, which had similar production, whereas milk production remained the same as the season progressed for cows kept at the low SR, 20.5, 19.3, and $20.1 \mathrm{~kg} / \mathrm{d}$, respectively, for periods 1,2 , and 3 . The decrease in milk production between periods 1 and 2 for cows grazing N-fertilized grasses at the high SR was likely because of the $46 \%$ decrease in HM during this time from 1,800 to $970 \mathrm{~kg}$ of DM/ha (Table 2). Kolver and Muller (1998) reported greater milk production associated with greater nutrient intake. Muller et al. (1995) reported that energy might be the most limiting nutrient when pastures are the major source of forage. Pregraze HM responses to grazing management were similar (viz., greater on low-SR treatments), suggesting an important role of HM on milk production from pasture-based systems. Additionally, forage and total OMI were greater when pregraze HM was greater on low-SR pastures. Milk production per animal was approximately $30 \%(5.5 \mathrm{~kg} / \mathrm{d})$ greater with low SR com- 
pared with high SR during the latter 2 periods of the study. The effects of SR in the present study support SR being a key grazing management variable, as has been reported by numerous studies (Fales et al., 1995; O'Brien et al., 1999).

Decreasing milk production as the season progressed was expected because all cows in the study were on the declining phase of the lactation curve (NRC, 2001). Cows grazing rotationally stocked temperate pastures in the northeast United States experienced a rapid decrease in milk production $(25 \%$; about twice the normal) during the first $8 \mathrm{wk}$ of a 24 -wk grazing season, after which the rate of decrease was more typical (Hoffman et al., 1993). In the present study, milk production decreased from period 1 to period 2 by about $16 \%$ but then increased by about $4 \%$ in period 3 . These data support the suggestion (Hoffman et al., 1993) that the decrease in milk production is more rapid initially when animals are put on pasture, but the rate of decrease in production tends to slow as the season progresses. Lack of decrease at low SR may be linked to greater forage mass and intake on these pastures.

Increasing the CS rate did not increase the milk yield. Concentrate supplementation for cows on grazedpasture systems may or may not result in increased milk production. This is likely coupled to supplementation rate and pasture quantity and quality characteristics (Jones-Endsley et al., 1997; O'Brien et al., 1999). The lack of CS effect may be linked also to stage of lactation. Typically, cows in the declining phase of lactation will tend to allocate energy to restoring body tissues that were mobilized to overcome energy deficits during periods of peak milk yields (NRC, 2001). Thus, along with the evidence in the current study that total DMI was similar between cows fed the 2 rates of CS, it is likely that milk production was not different because energy was being prioritized to body tissue stores. Berzaghi and Polan (1992) reported that cows on pasture fed cracked corn at $5.7 \mathrm{~kg} / \mathrm{d}$ had greater daily milk production than did unsupplemented cows (23.7 vs. $19.5 \mathrm{~kg} / \mathrm{cow})$. Milk production of Holstein cows grazing primarily orchardgrass (Dactylis glomerata L.) pastures and fed $1 \mathrm{~kg}$ of grain DM/4 kg of milk did not change when supplemented with $2.3 \mathrm{~kg} / \mathrm{d}$ of corn silage, mainly because of substitution of forage for corn silage (Holden et al., 1994). O'Brien et al. (1999) found that concentrate supplementation did not increase milk production in a 28-wk study when an adequate supply of herbage with good nutritive value was available.

\section{Milk Production per Hectare}

As expected, increasing the SR increased the total milk production per hectare; however, the increase was more pronounced during period 1 (97.1 vs. $51.2 \mathrm{~kg} / \mathrm{ha}$ ) than in periods 2 (74.5 vs. $48.4 \mathrm{~kg} / \mathrm{ha})$ and 3 (72.7 vs. $49.6 \mathrm{~kg} / \mathrm{ha}, \mathrm{SR} \times$ period interaction, $P<0.01$; Table 4). Neither the rate of CS nor the FM affected milk production per hectare.

Fales et al. (1995) reported that when cows were fed supplemental silage to maintain similar milk production per cow at different SR, milk production per hectare was greater at higher SR. Even though high SR may support greater milk production per unit of land area in the current study, at least in the short-term, such systems may not be sustainable if they lead to poor pasture persistence or loss in cow BW and BCS, and low reproductive performance.

Mean daily yield of $4 \%$ FCM per cow and per land area were influenced by the SR and period in the same way as uncorrected milk yield (Table 4). Perhaps because only trends existed toward differences in fat composition of milk in this study, no changes in statistical inferences were achieved by correcting for milk fat. Fales et al. (1995) obtained similar results in a study with Holstein cows grazing temperate pastures.

\section{Milk Composition}

The concentration of milk fat averaged $3.63 \%$ and was not influenced by treatment or period (Table 4). Milk fat concentrations obtained in the present study were within the range reported by several other studies (Hoffman et al., 1993; Holden et al., 1995; Kolver and Muller, 1998). Other researchers reported lack of effect of concentrate supplement on milk fat concentration of pasture-fed dairy cows (Hoffman et al., 1993; Holden et al., 1995; Kolver and Muller, 1998). Hoffman et al. (1993) suggested that adequate fiber was consumed from pasture and concentrate supplement so that milk fat concentration was maintained. More than $50 \%$ of the diet of animals in the present study was from pasture. Also, the grain-based concentrate fed included $30 \%$ soybean hulls and $20 \%$ whole cottonseed, which add a substantial amount of fiber to the diet.

Cows managed at the lower SR produced milk with greater $\mathrm{CP}$ content than those kept at greater SR (3.23 vs. $3.12 \%, P=0.04$; Table 5). Increased milk CP concentration is associated with increased microbial protein synthesis from highly digestible carbohydrate intake. If cows kept at the lower SR were able to select more digestible plant parts, digestible DMI may have been greater leading to increased production of microbial protein. Milk CP concentrations in the present study were similar to those reported in other studies (Hoffman et al., 1993; Fales et al., 1995; Holden et al., 1995).

During period 1, the concentration of MUN was greater for cows grazing $\mathrm{N}$-fertilized grass vs. grass- 
Table 5. Forage mixture (FM; N-fertilized grasses or grass-clover mixture), stocking rate (SR; high $=5$ cows $/$ ha, low $=2.5$ cows $/$ ha), and concentrate supplement rate $[\mathrm{CS}$; high $=0.40$ and low $=0.29 \mathrm{~kg}$ of supplement (as fed) $/ \mathrm{kg}$ of milk per day] effect on milk fat, milk CP, MUN, SCC, and $\triangle \mathrm{BW}$ during 3 consecutive 28 -d periods

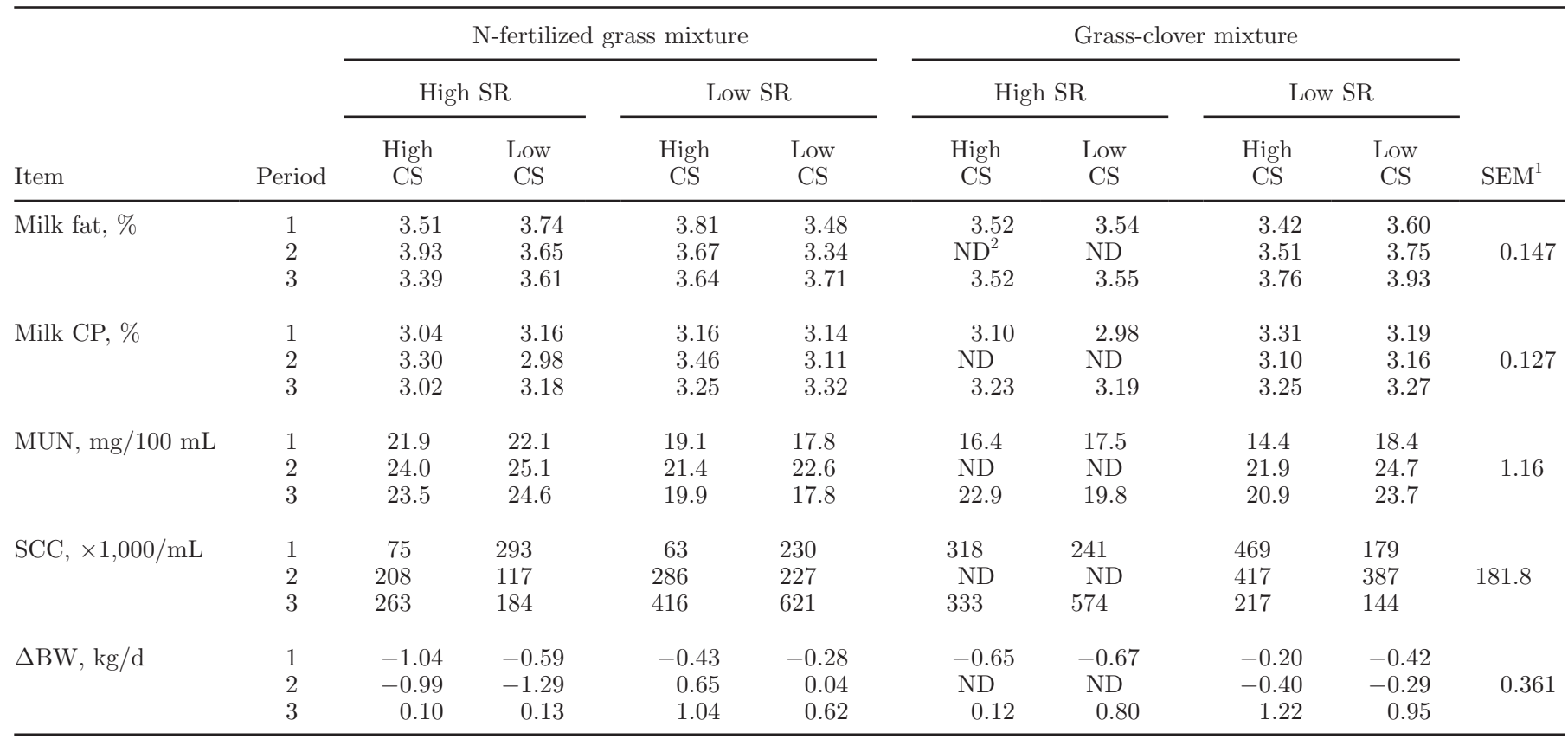

${ }^{1}$ SEM of 4-way interaction means (NS, $\left.P>0.10\right)$. Within responses, the significant effects are (a) milk fat, period $\times$ SR interaction trend $(P<$ 0.06. $\mathrm{SEM}=0.073)$; (b) milk CP, SR main effect $(P<0.04, \mathrm{SEM}=0.033)$; $(\mathrm{c}) \mathrm{MUN}, \mathrm{FM} \times \mathrm{SR} \times \mathrm{CS}$ interaction $(P<0.02 . \mathrm{SEM}=0.65)$ and period $\times$ FM interaction $(P<0.02, \mathrm{SEM}=0.58)$; and d) $\Delta \mathrm{BW}, \mathrm{SR}$ main effect $(P<0.01, \mathrm{SEM}=0.11)$ and period main effect $(P<0.001$, $\mathrm{SEM}=0.13)$.

${ }^{2}$ No data because cows were removed from these treatments for 3 wk because of low herbage mass.

clover pastures (20.2 vs. $16.7 \mathrm{mg} / 100 \mathrm{~mL}$ ) but MUN concentration did not differ due to FM in period $2(21.3$ vs. $23.3 \mathrm{mg} / 100 \mathrm{~mL})$ or $3(21.4$ vs. $21.8 \mathrm{mg} / 100 \mathrm{~mL}$, $\mathrm{FM} \times$ period interaction, $P=0.02$; Table 5). Also, cows kept on grass-clover pastures had lowest MUN concentration during period $1(16.7 \mathrm{mg} / 100 \mathrm{~mL})$ and similar MUN concentration during periods $2(23.3 \mathrm{mg} /$ $\mathrm{dL})$ and $3(21.8 \mathrm{mg} / 100 \mathrm{~mL})$. Alternatively, cows grazing $\mathrm{N}$-fertilized grass pastures had lowest MUN concentration in period $1(16.7 \mathrm{mg} / 100 \mathrm{~mL})$, which then increased in period $2(23.3 \mathrm{mg} / 100 \mathrm{~mL})$ and period 3 (21.5 mg/100 mL).

Additionally, cows grazing $\mathrm{N}$-fertilized grass pastures $(23.6 \mathrm{mg} / 100 \mathrm{~mL})$ had greater MUN concentrations than those on grass-clover pastures $(19.1 \mathrm{mg} / 100 \mathrm{~mL})$ when grazing at the high SR regardless of rate of CS. The FM had no effect on MUN concentrations at low SR when CS was high (20.1 vs. $19.1 \mathrm{mg} / 100 \mathrm{~mL})$ but a trend $(P=0.059)$ when CS was low was observed for MUN concentrations to be greater from cows grazing grass-clover pastures (22.2 vs. $19.4 \mathrm{mg} / 100 \mathrm{~mL}, \mathrm{FM} \times$ $\mathrm{SR} \times \mathrm{CS}$ interaction, $P=0.02$; Table 5).

Broderick and Clayton (1997) demonstrated that MUN concentration might serve as an index of inefficient utilization of dietary protein in the lactating dairy cow. These authors indicated that MUN concentrations above $14 \mathrm{mg} / 100 \mathrm{~mL}$ indicated an insufficient supply of fermentable energy per unit of $\mathrm{CP}$ or consumption of $\mathrm{CP}$ in excess of dietary need. Based on these values, MUN concentration data from the present study indicate that dietary protein was at or above requirements across treatments.

The mean SCC in milk were below the regulation maximum of 500. Treatments did not affect SCC values. In studies conducted in the northeastern United States, milk SCC was not different between pasture-fed and TMR-fed cows (Kolver and Muller, 1998) or cows managed at different SR (Fales et al., 1995).

\section{Animal BW Changes}

Cows grazing at the high SR lost BW $(-0.48 \mathrm{~kg} / \mathrm{d})$ whereas those kept on low SR gained BW $(0.21 \mathrm{~kg} / \mathrm{d}$, $P<0.01$; Table 5). Davidson et al. (1985) also reported that grazing cows lost more weight at higher SR. Cows lost BW during the first 2 periods of the study $(-0.53$ and $-0.49 \mathrm{~kg} / \mathrm{d}$, respectively) but gained BW during the third period $(0.62 \mathrm{~kg} / \mathrm{d}, P<0.001$; Table 5$)$.

Lactating dairy cows will mobilize body tissues when energy intake is insufficient to meet the demand for 
milk production (Ørskov and Ryle, 1990). In the present study, both milk production and BW gain were greater for cows at low SR, indicating that energy balance was better at low SR. The loss of BW during the start of the study likely reflects a decrease in nutrient intake when cows were transferred from a freestall housing, TMR-fed environment to pasture. Stability in BW was achieved as the grazing season progressed and with greater pasture HM in period 3. Loss of BW also was reported when dairy cows, usually managed in freestall systems, were transferred to grazed pasture (Jones-Endsley et al., 1997). Kolver and Muller (1998) reported that cows consuming only pasture suffered substantial BW losses $(1.1 \mathrm{~kg} / \mathrm{d})$ compared with TMRfed cows, likely because of lower DMI, but Holden et al. (1995) reported that BW and DMI did not change when corn silage and grain were supplemented to cows grazing temperate pastures.

\section{CONCLUSIONS}

Achieving optimal productivity of pasture forage and matching it with an appropriate animal SR are critical to successful management of pasture-based dairy operations. Stocking rate was the key factor affecting forage HM and allowance. Greater pregraze HM occurred at lenient SR, and accounted for greater HA. Milk production per animal benefited from greater pregraze HM and HA because of their beneficial effects on total nutrient intake. Greater SR allowed for increased production per hectare in spite of a decrease in production per cow. Body weight changes were positive toward the end of the trial, suggesting the need to explore whether body tissue mobilization is as drastic if animals are on pasture year-round compared with being kept in TMR-fed, confined systems and then moved to pastures for grazing studies. Overall, the results of this study suggest that, given current management strategies for intensive grazing of cool-season forages, successful winter grazing systems for moderate-producing dairy cows on sandy soils will more likely be rotationally-stocked N-fertilized rye-annual ryegrass pastures rather than grass-clover mixtures. Matching these forage systems with appropriate SR to ensure sufficient forage intake and avoid large losses in BW and condition is critical.

\section{REFERENCES}

Baltensperger, D. D., C. S. Jones, W. R. Ocumpaugh, K. A. Albrecht, and G. O. Mott. 1986. Comparisons of winter pasture systems for Florida. Pages 59-62 in Proc. 35th Beef Cattle Short Course. Anim. Sci. Dept., IFAS, Univ. of Florida, Gainesville.

Berzaghi, P., and C. E. Polan. 1992. Digesta passage in grazing lactating cows fed with or without corn. J. Dairy Sci. 75(Suppl. 1):223 (Abstr.)
Broderick, G. A., and M. K. Clayton. 1997. A statistical evaluation of animal and nutritional factors influencing concentrations of milk urea nitrogen. J. Dairy Sci. 80:2964-2971.

Burns, J. C., H. Lippke, and D. S. Fisher. 1989. The relationship of herbage mass and characteristics to animal responses in grazing experiments. Page 7 in Grazing Research: Design, Methodology, and Analysis. Crop Sci. Soc. Amer. Special Pub. No. 16. G. C. Marten, ed. Crop Sci. Soc. Amer. Inc., Madison, WI.

Burns, J. C., and L. E. Sollenberger. 2002. Grazing behavior of ruminants and daily performance from warm-season grasses. Crop Sci $42: 873-881$.

Chapman, D. F., A. J. Parsons, G. P. Cosgrove, D. J. Barker, D. M. Marotti, K. J. Venning, S. M. Rutter, J. Hill, and A. N. Thompson. 2007. Impacts of spatial patterns in pasture on animal grazing behavior, intake, and performance. Crop Sci. 47:399-415.

Davidson, T. M., R. T. Cowan, and R. K. Shepherd. 1985. Milk production from cows grazing tropical grass pastures. 2. Effects of stocking rate and level of nitrogen fertilizer on milk yield and pasture-milk yield relationships. Aust. J. Exp. Agric. 25:515-523.

Dougherty, C. T., N. W. Bradley, L. M. Lauriault, J. E. Arias, and P. L. Cornelius. 1992. Allowance-intake relations of cattle grazing vegetative tall fescue. Grass Forage Sci. 47:211-219.

Fales, S. L., L. D. Muller, S. A. Ford, M. O'Sullivan, R. J. Hoover, L. A. Holden, L. E. Lanyon, and D. R. Buckmaster. 1995. Stocking rate affects production and profitability in a rotationally grazed pasture system. J. Prod. Agric. 8:88-96.

Fisher, G. E. J., A. M. Dowdeswell, and G. Perrott. 1996. The effects of sward characteristics and supplement type on the herbage intake and milk production of summer-calving cows. Grass Forage Sci. 51:121-130.

Fontaneli, R. S., L. E. Sollenberger, and C. R. Staples. 2001. Yield, yield distribution, and nutritive value of intensively managed warm-season annual grasses. Agron. J. 93:1257-1262.

Gallaher, R. N., C. O. Weldon, and J. G. Futral. 1975. An aluminum block digester for plant and soil analysis. Soil Sci. Soc. Am. Proc. 39:803-806.

Golding, E. J., M. F. Carter, and J. E. Moore. 1985. Modification of the neutral detergent fiber procedure for hays. J. Dairy Sci. 68:2732-2736

Hambleton, L. B. 1977. Semiautomated method for simultaneous determination of phosphorus, calcium, and crude protein in animal feeds. J. Assoc. Off. Anal. Chem. 60:845-854.

Hoffman, K., L. D. Muller, S. L. Fales, and L. A. Holden. 1993. Quality evaluation and concentrate supplementation of rotational pasture grazed by lactating cows. J. Dairy Sci. 76:2651-2663.

Holden, L. A., L. D. Muller, T. Lykos, and T. W. Cassidy. 1995. Effect of corn silage supplementation on intake and milk production in cows grazing grass pasture. J. Dairy Sci. 78:154-160.

Holden, L. A., L. D. Muller, G. A. Varga, and P. J. Hillard. 1994. Ruminal digestion and duodenal nutrient flows in dairy cows consuming grass as pasture, hay, or silage. J. Dairy Sci. 77:3034-3042.

Holmes, C. W., C. J. Hoogendoorn, M. P. Ryan, and A. C. P. Chu 1992. Some effects of herbage composition, as influenced by previous grazing management, on milk production by cows grazing on ryegrass/white clover pastures. 1. Milk production in early spring: Effects of different regrowth intervals during the preceding winter period. Grass Forage Sci. 47:309-315.

Hoogendoorn, C. J., C. W. Holmes, and A. C. P. Chu. 1992. Some effects of herbage composition, as influenced by previous grazing management, on milk production by cows grazing ryegrass/white clover pastures. 2. Milk production in late spring/summer: Effects of grazing intensity during the preceding spring period. Grass Forage Sci. 47:316-325.

Jones-Endsley, J. M., M. J. Cecava, and T. R. Johnson. 1997. Effects of dietary supplementation on nutrient digestion and milk yield of intensively grazed lactating dairy cows. J. Dairy Sci. 80:3283-3292.

Kolver, E. S., and L. D. Muller. 1998. Performance and nutrient intake of high producing Holstein cows consuming pasture or a total mixed ration. J. Dairy Sci. 81:1403-1411. 
L'Huillier, P. J. 1987. Effect of dairy cattle stocking rate and degree of defoliation on herbage accumulation and quality in ryegrass-white clover pasture. N. Z. J. Agric. Res. 30:149-157.

Littell, R. C., G. A. Milliken, W. W. Stroup, and R. D. Wolfinger. 1996. SAS system for mixed models. SAS Institute Inc., Cary, NC.

Macoon, B., L. E. Sollenberger, J. E. Moore, C. R. Staples, J. H. Fike, and K. M. Portier. 2003. Comparison of techniques for estimating the forage intake of lactating dairy cows on pasture. J. Anim. Sci. 81:2357-2366.

Mertens, D. R. 1994. Regulation of forage intake. Pages 450-493 in Forage Quality, Evaluation, and Utilization. G. C. Fahey, Jr., M. Collins, D. R. Mertens, and L. E. Moser, ed. ASA, CSSA, SSSA, Madison, WI.

Moore, J. E., and G. O. Mott. 1974. Recovery of residual organic matter from in vitro digestion of forages. J. Dairy Sci. 57:1258-1259.

Moss, R. J., and K. F. Lowe. 1993. Development of forage systems for dairying in subtropical Australia. Pages 1991-1992 in Proc. Int. Grassl. Congress, 17th, Palmerston North, New Zealand. M. J. Baker, J. R. Cush, and L. R. Humphreys, ed. Keeling and Mundy Ltd., Palmerston North, New Zealand.

Muller, L. D., E. S. Kolver, and L. A. Holden. 1995. Nutritional needs of high producing cows on pasture. Pages 106-120 in Proc. Cornel Nutr. Conf. Feed Manuf., Rochester, NY. Cornell Univ., Ithaca, NY.
NASS. 2009. Florida State agriculture overview-2009. National Agricultural Statistics Service, Florida Statistics and Reports. Accessed Aug. 12, 2010. http://www.nass.usda.gov/Statistics_by_ State/Florida/index.asp.

NRC. 2001. Nutrient Requirements of Dairy Cattle. 7th rev. ed. National Research Council, National Academies Press, Washington, DC

O'Brien, B., P. Dillon, J. J. Murphy, R. J. Mehra, T. P. Guinee, J. F. Connolly, A. Kelly, and P. Joyce. 1999. Effects of stocking density and concentrate supplementation of grazing dairy cows on milk production, composition, and processing characteristics. J. Dairy Res. 66:165-176.

Ørskov, E. R., and M. Ryle. 1990. Energy Nutrition in Ruminants. Elsevier Applied Science, New York, NY.

SAS Institute. 1991. SAS User's Guide: Statistics. SAS Institute Inc., Cary, NC.

Sollenberger, L. E., J. E. Moore, V. G. Allen, and C. S. Pedreira. 2005. Reporting forage allowance in grazing experiments. Crop Sci. 45:896-900.

Sollenberger, L. E., and E. S. Vanzant. 2011. Interrelationships among forage nutritive value and quantity and individual animal performance. Crop Sci. 51:420-432. 